\title{
Metascience symbols (universal characteristic)
}

\author{
K. I. BAKHTIYAROV
}

\begin{abstract}
Leibniz called the first article "New method maximums and minimums". Instead of considering the realisation of the method for maximums and minimums, it should have been considered from symbolic side as the Universal characteristic. The extremums as symbols of universal language covers all infinity of the certain subjects sense of which it is. Creation of a block matrix (by means of the left tensor square) allowed to reveal macrolevel and circular arrangement of charts. And in philosophy of a science there is no other way to follow the Nature except to follow to genetics. The logic reduction of a non-classical multi-valuedness to classical binarity of the designated and anti-designated values forms overlaps from right to left and from left to right, forming a hysteresis loop arranging the circular order. The complementarity of levels generates fractality of the main table structure.
\end{abstract}

Keywords: characteristic, extremums, designated, anti-designated values, fractality, logic reduction

Part of the secret of analysis is the art of using notations well.

Leibniz

I had to screen out the closed space, concentric universum..., where the whole life is measured by canonical hours.

U. Eco. Postscript to The Name of the Rose

If measuring time in dozens and grosses (dozen of dozens) like in Herbert Wells's novel "When the Sleeper Wakes", it is possible to show that in 1 gross of years ( \pm 1 year) there are many important historical events: 


\begin{tabular}{|l|l|}
\hline 1773 - Pugachev's rebellion & 1917 - October revolution \\
\hline $\begin{array}{l}1799 \text { - Suvorov's crossing of the } \\
\text { Alps }\end{array}$ & $\begin{array}{l}1945 \text { - Zhukov's crossing of the } \\
\text { Vistula and the Oder }\end{array}$ \\
\hline 1825 - Decembrist Uprisings & 1968 - The Prague spring \\
\hline 1835 - Herzen's exile & 1980 - Sakharov's exile \\
\hline $\begin{array}{l}1842 \text { - Herzen's return from the } \\
\text { exile }\end{array}$ & $\begin{array}{l}1986 \text { - Sakharov's return from } \\
\text { the exile }\end{array}$ \\
\hline
\end{tabular}

Involuntarily Lenin's known statement occurs: "Decembrists have woken Herzen...". It seems, scientific revolutions occur twice less often. This article is about one of them. Leibniz called the first article "New method for maximums and minimums". And in 2 grosses of years after his death $(1716+288=2004)$ the author of these lines continues his work and proposes to use the signs of extremums as symbols of universal language [2]. By the way, dates of birth of the authors also differ by 2 grosses of years.

Instead of considering the realisation of the method, it should have been considered from symbolic side as the Universal characteristic. Let's show that extremums as symbols of universal language "covers all infinity of the certain subjects sense of which it is" [10].

Mathematics has the exact classification of extremums maximums and minimums which are subdivided into smooth (derivative $\left.y^{\prime}=0\right)$ and sharp (derivative $y^{\prime}$ does not exist).

\subsection{Maximums}

1.1 Sharp maximums

1.2 Smooth maximums

2.0 Minimums

2.1 Sharp minimums

1.2 Smooth minimums

\begin{tabular}{cc|c|}
\multirow{2}{*}{ Maximum } & \multicolumn{1}{c}{ Smooth } & Sharp \\
\cline { 2 - 3 } Minimum & $\cap$ & $\wedge$ \\
\cline { 2 - 3 } & $\cup$ & $\vee$ \\
\hline
\end{tabular}


Logic has been using signs of extremums: the disjunction is traditionally designated by minimum sign $(\mathrm{V})$, and conjunction - by maximum sign $(\wedge)$ though they are calculated vice versa. Extremums are symbols of universal language. Complementary pairs fit each other as parts of a puzzle or male contact - female contact and used also for letters of a genetic code [4]. Maximums $\cap, \wedge$ are convenient to designate by the letters $\mathbf{n}$ and $\mathbf{A}$, and minimms $\cup, \vee-$ by the letters $\mathbf{u}$ and $\mathbf{V}$.

Each scientific revolution has 4 stages: ${ }^{*}$ growth, ${ }^{*} \mathbf{A}$ maximum, ${ }^{*} \mathrm{u}$ decline, ${ }^{*} \mathbf{V}$ minimum. T. Kuhn in the book "The structure of scientific revolutions" emphasized: "A decision between alternate ways of practicing science is called for, and in the circumstances that decision must be based less on past achievement than on future promise". He focused attention on the "Normal" science (with a constant paradigm) that has not allowed it to describe structure of scientific revolutions (with change of paradigms) [12]. Only after considered logic structure of dominants and not dominants, it is possible to formulate structural principles of scientific revolutions.

All two-letter words are formed by application of "letters" to themselves, providing a quantum leap to the highest level [4, p. 129]. Elements of microlevel take the meaning only in a macrolevel context. In pairs $(x, y)$ a prefix $x=$ MICROLEVEL (name), and a radical $y=$ MACROLEVEL (surname). These elements of microlevel form macrolevel BLOCKS. Capital letters of radical dominants have a priority, and small letters of nondominant radicals provide the priority to any letters of prefixes. The Designation is provided by vowels and anti-designation - by consonants.

The complementary pair of vowels $\mathbf{A}, \mathbf{u}$ transfers a voice. When substituting sound (de facto) with the letter (de jure) the relations within the cycle are disrupted, when capital letter $\mathbf{A}$-summer (passionarity overheat) and $\mathbf{V}$-winter become similar (by a form). A letter is a death for living. Genesis demands to overcome this serfdom. Freedom of a living word is necessary.

The genetic table of pairs has 4 blocks and phases b, q, p, d: 


\begin{tabular}{|c|c|c|c|c|c|c|c|c|c|c|}
\hline Cons/ & Vowels & & & & & $3 /$ & $6 \mathrm{mo}$ & $\lg 9$, & 12 & afternoon \\
\hline \multirow[t]{2}{*}{${ }^{*} \mathrm{n}$} & \multirow[t]{2}{*}{${ }^{*} \mathrm{~A}$} & \multirow[t]{2}{*}{$\mathrm{d}$} & \multirow[t]{2}{*}{$\mathbf{b}$} & \multirow[t]{2}{*}{$\mathbf{q}$} & \multirow[t]{2}{*}{$\mathbf{p}$} & $\mathrm{nn}$ & An & $\mathbf{n A}$ & AA & \\
\hline & & & & & & $\mathrm{Vn}$ & un & VA & $\mathbf{u A}$ & \\
\hline \multirow[t]{2}{*}{$* \mathrm{~V}$} & \multirow[t]{2}{*}{${ }^{*} \mathrm{u}$} & \multirow[t]{2}{*}{$\mathrm{p}$} & \multirow[t]{2}{*}{$q$} & \multirow[t]{2}{*}{$\mathrm{b}$} & \multirow[t]{2}{*}{ d } & $\mathrm{nV}$ & $\mathrm{AV}$ & $\mathrm{nu}$ & $\mathrm{Au}$ & \\
\hline & & & & & & VV & $\mathrm{uV}$ & $\mathrm{Vu}$ & uu & \\
\hline
\end{tabular}

Circulation phases (clockwise):

the designated pairs

the anti-designated pairs $\mathbf{b}, \mathbf{q}$

(6, 9 of the morning),

b, $q$

(6, 9 of the evening), p, d

(12, 3 of the afternoon),

$\mathrm{p}, \mathrm{d}$

(12, 3 of the night).

The S-shaped border of the designated and anti-designated pairs forms the Yin-Yang figure.

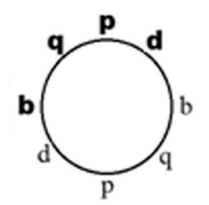

New symbols of the dial are constructed so when change of interblock transition $\mathbf{b}, \mathbf{q}$ and $\mathbf{p}, \mathbf{d}$ is big ("interval long") we have turned image, and when change of interblock transition $\mathbf{d} \mid \mathbf{b}$ and $\mathbf{q} \mid \mathbf{p}$ is small ("interval short") we have mirror image.

Complete character of DOMINANTS is provided by submission to capital vowel or concordant of the radical and vague character of non-dominants (with small letters of the radical) - by change of submission to vowel and concordant of the prefix. The mechanism of revolution and change of paradigms should be learnt. Small change in transitional demiblocks prepares great change between blocks. The majority does not perceive small change that generates errors of the 1st and 2nd kind. In hindsight errors are perceived as prediction and afteraction phantoms respectively.

On the basis of equality the matrix is divided into two halves fifty-fifty: accepted (A) and rejected (R) values. They do not always coincide with true $(\mathrm{T})$ and false $(\mathrm{F})$ values. Small change from $\mathrm{F}$ to $\mathrm{T}$ (as well as from $\mathrm{T}$ to $\mathrm{F}$ ) prepares a large change from $\mathrm{R}$ to $\mathrm{A}$ (as 
well as from A to R) by means of transitional "phantoms" - errors of the first kind ( $\mathrm{RT}=$ rejected true) and errors of the second kind $(\mathrm{AF}=$ accepted false $)$. According to V.A. Lefebvre we have the first ethical system with presumption of innocence (during "brain storm" it is forbidden to criticize at all) and the second ethical system with a guilt presumption ("witch hunt") [4, p. 60].

The reduction of multi-valuedness is solved by dominants with priority of macrolevel radical over microlevel prefix. Adjacent pairs reverse in the identity on designation: $\mathbf{A u}=\mathbf{u A}$. Diagonal oppositions of the designated and anti-designated true-false pairs anti-commutate in identity on designation: $\mathrm{AV}=-$ VA. Midday and midnight - are in antiphase as antipodes on the offered dial of the designated and anti-designated pairs. The anti-commutativity does not hide non-identity of the paradigm and anti-paradigm, but prepares qualitative transfer. Here the complementarity principle is fundamental, and N. Bohr considered nonclassical noncommunicativity as its most essential manifestation. "The noncommutativity formula turned from striking absurd into the unforeseen guarantee of the fruitfulness of the discovered way" [5, p. 259]. One of sources of complementarity principle is the principle of compliance generating fractality of the main table.

The dial describes a circular order of the genetic code diagrams and socionics quadras well [3]. Diagonal oppositions are complementary. "They teetered on scales: the morning raised one, the evening raised another" [6, p. 349]. Not without reason the saying tells: "The morning is wiser than the evening". Von Weizsecker was the first who paid attention that complementary descriptions are in the circular relation. He associates the complementarity concept with the general gnoseological model of "the circle of knowledge" [1, p. 159, 193]. It is necessary to join his opinion that this concept is in essence logical.

The Earth's rotation around its own axis and its rotation around the Sun can serve as a bright example of a temporary fractality: day periods (morning, day, evening, night) are similar to seasons (spring, summer, autumn, winter). Ptolemaeus's epicycles of heavenly bodies [5] and Ibn al-Arabi's concentric circles [8] are characteristic for a metascience (astrology and alchemy). Its sectors 
(Speaking, Loving, Knowing and Dominating) does not casually seen similar to the modern classification in the sotsionics.

Aristotle's LOGICAL SQUARE quartered Natural Universal but "presented" to it a prison cell with a square outlook. Unlike the European astrological charts, of the rectangular shape, the Arabian charts traditionally had the round shape. Later the circular order prevailed in Europe as well. The striking examples are the round seal inherited from alchemists, and R. Lully's logical machine. Later the bishop J. Wilkins in his universal language used the arrows received by turn on multiple angles as symbols. Now the matrix provided the circular arrangement ( $n$ "spring" - A "summer" - u "autumn" - $V$ "winter") in MATRIX OF GENESIS unlike the LOGIC SQUARE:
n. spring
A. SUMMER
n. spring
A. SUMMER
V.WINTER
u. autumn
u. autumn
V.WINTER

Aristotle applied the logic square in syllogistics where partial affirmative and partial negative judgments were nearby in one column, and general affirmative and general negative judgments are nearby in other column. Figuratively in that case summer and winter are nearly. A. Koyre believed that "the theoretical thought and human life are separated by a chasm" [15]. He underlined this thesis, stating that the world of the science is leaving and separates from the living world. Logic "presented" us civilization with square outlook. Within it it is impossible to overcome the gap between adjacent maximum A ("summer") and minimum V ("winter"). The living logic with the Matrix of Genesis allows to define the features matching the plan of the Nature. Creation of a block matrix (by means of the left tensor square) allowed to reveal macrolevel and circular arrangement of charts. The genetic code is information code. And in philosophy of a science there is no other way to follow the Nature except to follow to genetics.

G. Frege in "Logic" wrote: "Laws of the nature do not need our recognition to be true". For a sample of letters of universal language the author took letters of extremum signs. As a prototype for a symbol of a maximum was the letter $\boldsymbol{A}$ (adenine), and the 
letter $\boldsymbol{u}$ (uracil) was the symbol of weak minimum. For another complementary pair the similar turned signs were taken: a letter $\mathbf{V}$ (cytosin) as a minimum sign, and a letter $\mathbf{n}$ (guanine) as a sign of a weak maximum [4, pp. 128-130]. Notice that in alchemy the truncated triangle of the fire sign (top up) was the air sign, and the water sign was the truncated triangle of the earth sign (top down). The initial matrix is made up of the complementary pairs of consonants $(\mathrm{n}, \mathrm{V})$ and vowels $(\mathrm{A}, \mathrm{u})$. Accordants provide stability of the concaved (caved in under the power) consonants ${ }^{*} \mathbf{V}$, and discordants provide variability of convex vowels (arising dissidents) ${ }^{*} \mathbf{A}$.

Let's start with the complementarity concept. A. Petersen sees its historical and philosophical reasons in the problem of stability and variability [16]. Divisible, changeable elements form a logic wave, and indivisible, stable elements form a logic atom which has the quadruple duplication that provides the higher noise immunity when transferring the genetic information. Stability takes place, when the third wheel is in triplet; and variability is mutability among alternatives. The designated values for digrams which generate more than one amino acid, are characteristic for the first ethical system, and non-designated values are the codes generating the unique amino acid (that provides stability at the expense of redundancy).

The consideration of non-classical logic in terms of the classical logic allows to show clearly reduction role for obtaining the designated values. The logic reduction of a non-classical multivaluedness to classical binarity of the designated and antidesignated values forms overlaps from right to left and from left to right, forming a hysteresis loop arranging the circular order. The overlaps from right to left and from left to right, forming a hysteresis loop are well described by the dial of genetic code and quadras of socionics. This certain "inertia" which is noticed long ago by experts in psychophysics, provides the model of wave genetics which is visually drawing a S-shaped wave of the Yin-Yang figure.

As oppositions J. Derrida considers night well (North) and day Egyptian pyramid (South) - underground and elevated architecture [7]. The way between them lies through a morning 
source (East). The beginning is that has become. As a whole the way is circular. P. Valery traced the source (la source): "We are made of two moments, and as though of delay of the thing in relation to itself ... Between Life and Knowledge the powerful and aimless music operates" [9]. The poet composing verses from wordssigns is some kind of intermediary between two poles. Mallarme's music is splashed out on a surface of poetic language, filling in the deepest hollows of creative thinking, becoming the most intimate occupation. The world which draws language cognition should be corrected having learnt its reality by means of music.

The role of reduction for understanding of the phenomenon of consciousness in terms of quantum mechanics was repeatedly emphasised by physicists: "the information of microsystem is recorded through the macrosystem state change" [11]. The secret is revealed not via metaphysics, but through metachemistry. The main thing is not microlevel chemistry but macrolevel alchemy of which D. Hofstadter dream [14]. It makes true Leibniz's dream to make mathematics really universal language. The model offered allows to track visually the large-block construction of the logic matrix, and then the arrangement of separate cells which are filled according to the principle of similarity [4]. Position record needs only 4 letters at the highest levels. The positioning principle is inherent for analytic approach and for humanities it offers not less advantages, than for arithmetics.

The geometry is the most ancient mathematical discipline, and the higher geometry (which is usually called projective geometry) showed how to make the uniform scheme for classical and nonclassical theories. The best thinkers of all times looked at it as at excellent exercise in logic, extremely suitable for development of great minds [15]. Homogeneous coordinates serve as guiding star, allowing to provide the final representation of infinite values. To fulfill the synthesis of classical and non-classical theories the higher logic is required which is generated by projective interpretation of a Boolean multi-valuedness [4, p. 158-161].

Asymptotic correspondence of classical and non-classical theories is manifestation of the principle of compliance which establishes connection between these representations. The complementarity 
of levels generates fractality (self-similarity) of the main table structure. The offered genetic method to solve the problem of transition from one paradigm to another is the message which provides the clue to cognitive process that will help fill the gap between natural intelligence (NI) and artificial intelligence (AI).

\section{Appendix. Arithmetization of Matrix Genetics}

Genome appears as a sample of the text noted by four letters of a universal code. The Matrix of Complementary is made on the basis of complementary pairs. For example the pair $\mathrm{A}-\mathrm{u}$ in which we will use letter $\mathrm{A}(=\mathrm{A}$, adenine) as a maximum sign, and a letter $\mathrm{u}(=\mathrm{u}$, uracil $)$ as weak minimum sign. Capital letter is always complementary to the small one. For another complementary pair we take the turned signs: a letter $\mathrm{V}(=\mathrm{C}$, cytosin $)$ as a minimum sign, and a letter $\mathrm{n}(=\mathrm{g}$, guanine) as a sign of a weak maximum. In the matrix genetics based on (right) Kronecker tensor square we have blocks by the first letters:

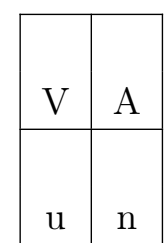

\begin{tabular}{|c|c|c|c|}
\hline $\mathrm{VV}$ & $\mathrm{VA}$ & $\mathrm{AV}$ & $\mathrm{AA}$ \\
$\mathrm{Vu}$ & $\mathrm{Vn}$ & $\mathrm{Au}$ & $\mathrm{An}$ \\
\hline $\mathrm{uV}$ & $\mathrm{uA}$ & $\mathrm{nV}$ & $\mathrm{nA}$ \\
$\mathrm{uu}$ & $\mathrm{uV}$ & $\mathrm{nu}$ & $\mathrm{nn}$ \\
\hline
\end{tabular}

\begin{tabular}{|c|c|c|c|}
\hline 6 & 5 & 5 & 4 \\
5 & 6 & 4 & 5 \\
\hline 5 & 4 & 6 & 5 \\
4 & 5 & 5 & 6 \\
\hline
\end{tabular}

The bad thing is that there is no simple order in the bold cell positions generating codons richer with amino acids (more than one). There is no simple order in the position of the cells with numbers of hydrogen bonds (for example, cells with $\mathrm{p}=5$, organising an "epicycle").

In the matrix genetics based on non-Kronecker (left) tensor square we have blocks by the second letters. Then we receive a block matrix with clusters by arguments and columns by number of hydrogen bonds.

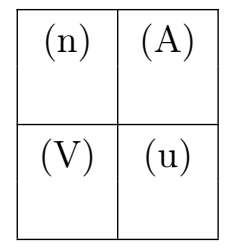

\begin{tabular}{|c|c|c|c|}
\hline $\mathrm{nn}$ & $\mathbf{A n}$ & $\mathbf{n A}$ & $\mathbf{A A}$ \\
$\mathrm{Vn}$ & $\mathbf{u n}$ & $\mathbf{V A}$ & $\mathbf{u A}$ \\
\hline $\mathrm{nV}$ & $\mathrm{AV}$ & $\mathrm{nu}$ & $\mathbf{A u}$ \\
$\mathrm{VV}$ & $\mathrm{uV}$ & $\mathrm{Vu}$ & $\mathbf{u u}$ \\
\hline
\end{tabular}

\begin{tabular}{|l|l|l|l|}
\hline $\mathbf{6}$ & $\mathbf{5}$ & $\mathbf{5}$ & $\mathbf{4}$ \\
6 & $\mathbf{5}$ & 5 & 4 \\
\hline 6 & 5 & 5 & 4 \\
6 & 5 & 5 & $\mathbf{4}$ \\
\hline
\end{tabular}


Matrix of Complementary will be divided into columns complementary pairs. The block matrix has 1 cluster and 2 semiclusters - "bold", richer with corresponding amino acids (more than 1 amino acids in the cell).

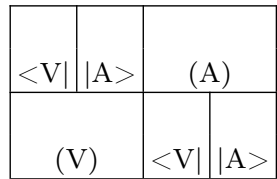

\begin{tabular}{|c|c|}
\hline$<\mathrm{V} \mid \mathrm{A}>$ & $(\mathrm{A})$ \\
\hline$(\mathrm{V})$ & $<\mathrm{V} \mid \mathrm{A}>$ \\
\hline
\end{tabular}

\begin{tabular}{|l|c|c|c|}
\hline gly & STOP, / -ser & glu/ asp & lys/asn \\
\hline arg & $\operatorname{trp} /$ cys & gln/his & -STOP $/$ tyr \\
\hline ala & thr & val & $\underline{\underline{\text { met } / \text { ile }}}$ \\
\hline pro & ser & leu & $\underline{\underline{\text { leu }} / \underline{\underline{\text { phe }}}}$ \\
\hline
\end{tabular}

So, we have two strong, dominant arguments (A) - top of liberalism which is "polygamous", and (V) - the conservatism whirlpool is "monogamous".

Universal symbols show isomorphism of genetic code tables and Jung's mental types. When interpreting the elements of matrices we proceeded from the division into similar cells that generates fractalirty. Isomorphism of matrices of genetic code and mental types shows roneness of the characters in many respects defined by their genetic code [4, p. 186-187].

\section{References}

[1] Alekseev I.S. Koncepciya dopolnitel'nosti. M., 1978 (in Russian).

[2] Bakhtiyarov K.I. Simvoly universal'nogo yazyka i geneticheskii kvadrat dominant // Vestnik MGU. Ser. 7. Filosofiya. 2004. № 5. S. 52-59 (in Russian).

[3] Bakhtiyarov K.I. Geneticheskii metod dlya stilei myshleniya // Metafizika. № 1(3). 2012. S. 167-174 (in Russian).

[4] Bakhtiyarov K.I. Arithmetization of Matrix Genetics // Logika i psihogenetika s tochki zreniya informatiki. M., 2013.

[5] Gindilis L.M. Geocentricheskaya i geleocentricheskaya sistemy mira s pozicii metanauchnogo znaniya // Trudy seminara "Problemy kosmicheskogo myshleniya i Jivoi Etiki". Tom 2. Vyp. 2/4. M., 2012. S. 19-21 (in Russian).

[6] Danin D.S. Nil's Bor. M., 1978. S. 259, 349 (in Russian).

[7] Derrida J. Marges de la phylosophie. Paris, 1972. P. 4, 88, 177, 330.

[8] Ibn al-Arabi. Izobrajenie okrujnostei, ohvatyvayuschih podobie cheloveka Tvorcu i sotvorennomu miru // Ibn al-Arabi. Mekkanskie otkroveniya. SPb., 1999. S. 69 (in Russian). 
[9] Kozovoi V. Pol' Valeri v poiskah intellektual'nogo universalizma // Tainaya os'. Izbr. proza. M., 2003. S. 278 (in Russian).

[10] Losev A.F. Problema simvola i realisticheskoe iskusstvo. M., 1976. S. 65 (in Russian).

[11] Menskii M.B. Fenomen soznaniya s tochki zreniya kvantovoi mehaniki // Metafizika. № 1(3). 2012. S. 103 (in Russian).

[12] Prujinin B.I. Ratio serviens? Kontury kul'turno-istoricheskoi epistemologii. M., 2009. S. 144 (in Russian).

[13] Bakhtiyarov K.I. The dial of the circular complementarity of the designated and antidesignated pairs // Studia Humana. Volume 1: 3/4. 2012.

[14] Hofstadter D. I am a Strange Loop. N.Y., 2007. P. 235.

[15] Koyré A. Etudes new tonniennes. Paris, 1968. P. 43.

[16] Petersen A. Quantum physics and the philosophical tradition. Cambridge, 1968. P. 62. 